Swarthmore College

Works

1994

\title{
The Fictional Republic: Horatio Alger And American Political Discourse
}

Carol Nackenoff

Swarthmore College, cnacken1@swarthmore.edu

Follow this and additional works at: https://works.swarthmore.edu/fac-poli-sci

Part of the Political Science Commons

Let us know how access to these works benefits you

\section{Recommended Citation}

Carol Nackenoff. (1994). "The Fictional Republic: Horatio Alger And American Political Discourse". The Fictional Republic: Horatio Alger And American Political Discourse.

https://works.swarthmore.edu/fac-poli-sci/111

This work is brought to you for free by Swarthmore College Libraries' Works. It has been accepted for inclusion in Political Science Faculty Works by an authorized administrator of Works. For more information, please contact myworks@swarthmore.edu. 


\title{
3
}

\section{Republican Rites of Passage: Character and the Battle for Youth}

So far as success in the world is concerned, all depends upon a few short years-upon the character you form in this spring season of your being.

Joel Hawes, Lectures to Young Men ${ }^{1}$

Were I to define what I mean by character, I say it is that which makes free and intelligent beings have confidence in you.

John Todd, The Young Man: Hints Addressed to the Young Men of the United States ${ }^{2}$

\begin{abstract}
Almost all of the products of Alger's pen featured-and were directed toboys and girls on the verge of adolescence. If those addressed stood on the threshhold of life and their habits were just becoming formed, they increasingly faced this critical period of life away from home. ${ }^{3}$ In antebellum America, "a number of clergymen, teachers, and sentimental writers confronted the moral problem generated by ... mass migration [from the country to booming cities] in dozens of manuals of advice to American youth ..." Alger, too, directed his attention to youth who, leaving familiar surroundings and community networks for the city in ever-increasing numbers and at ever-younger ages, were cut adrift from traditional moral influences of family, clergy, and friends. In dangerous new surroundings, the young must learn to grow and adapt while keeping their identity as members of the Republic intact.
\end{abstract}


This transition was of the utmost import for the youth's spiritual and temporal well-being. Moreover, it was crucial for those who believed that the only way to ensure the survival of the Republic lay in preserving the character of the new generation. ${ }^{5}$

Alger's basic story may be read as an allegory. This chapter explores parallels between the rites of passage of young heroes and those of the young Republic. Each seeks to maintain a core of identity and establish its virtue through the dangerous passage. The trials of the young are the trials of the Republic. In the success of the former lies the triumph of the latter. Entering its adolescence, facing Civil War, immigration, urbanization, industrialization, increasing polarization of rich and poor, corruption, greed, materialism and selfishness - all of which threaten to tear it apartthe Republic's triumph lay in the preservation of virtue, meaning its integrity, identity, independence, and freedom. Alger's fiction does battle for the Republic.

Allegory plays an important role in the appeal of the Alger story. Confronting and overcoming the dangers against which many Alger contemporaries inveighed, the young fictional figures offer an optimistic prognosis for the future of the Republic. The boy of good character could prevail; the Republic as growing youth is offered reassurance. ${ }^{6}$

\section{ALLEGORY OF THE REPUBLIC}

Society is a man in a larger form, and we are all members, and must act in concert with the rest, and do our duty to the whole, or we shall find ourselves-like a hand that lies inactively appropriating the life-blood that flows into it, without doing any thing for the whole body-gradually losing our power, and withering away into mental impotency.

T. S. Arthur, Advice to Young Men on Their Duties and Conduct in Life?

Alger's most frequent central character is a boy from fourteen to sixteen years old who is thrust into a new environment, almost always the city. The story is a rite of passage from boyhood to manhood during which the youth must undergo many trials. The completion of the passage yields a young adult whose virtue is firm; the adolescent of the Republic attains manhood. ${ }^{8}$ 
In one variant of the theme, however, a child who is too young to be cast adrift is returned to dependency - to adoptive parents-who will provide the education and moral guidance that will enable the youth to make the rite of passage later. Victory preserves virtue as the youth is saved from having to enter the world of adulthood unequipped for struggle. Julius, the Street Boy; Mark, the Match Boy; and Phil, the Fiddler are among the stories in which the victory lies in adoption or recovery by surrogate parents.

Female street children are at risk and must be rescued as well. On the streets, they had little to look forward to. According to Brace, who set up a lodging house that provided instruction in morals and in economic selfsufficiency for some of these girls, many female street children could be expected to end up in a life of prostitution. ${ }^{9}$ Heroine Tattered Tom is, in fact, a young street girl of twelve, posed on the brink of adolescence. Alger rescues her just in the nick of time and returns her to the care and moral supervision of her long lost mother. Better yet, a vehide is provided for the salvation of more girls:

For her sake, her mother loses no opportunity of succoring those homeless waifs, who, like her own daughter, are exposed to the discomforts and privations of the street, and through her liberality and active benevolence more than one young Arab has been reclaimed, and is likely to fill a respectable place in society. ${ }^{10}$

One could say of Alger'smaleand femalecharacters, a fewyearsyounger than Dreiser's Caroline Meeber, who entered Chicago in the summer of 1889:

When a girl leaves her home at eighteen, she does one of two things. Either she falls into saving hands and becomes better, or she rapidly assumes the cosmopolitan standard of virtue and becomes worse ... Half the undoing of the unsophisticated and natural mind is accomplished by forces wholly superhuman. A blare of sound, a roar of life, a vast array of human hives, appeal to the astonished senses in equivocal terms. Withouta counsellor at hand to whisper cautious interpretations, what falsehoods may not these things breathe into the unguarded ear! ${ }^{11}$

Excessive materialism was only one of many temptations a boy or girl faced in the city; the threats to character and virtue were legion. "Young people are easily drawn into any scheme, merely from its being new, especially if it falls in with their love of pleasure; but they are almost as easily discouraged from it by the next person they meet with." ${ }^{12}$ For the moralist, intervention was critical. The link between individual character formation and the welfare of the community was unquestioned: 


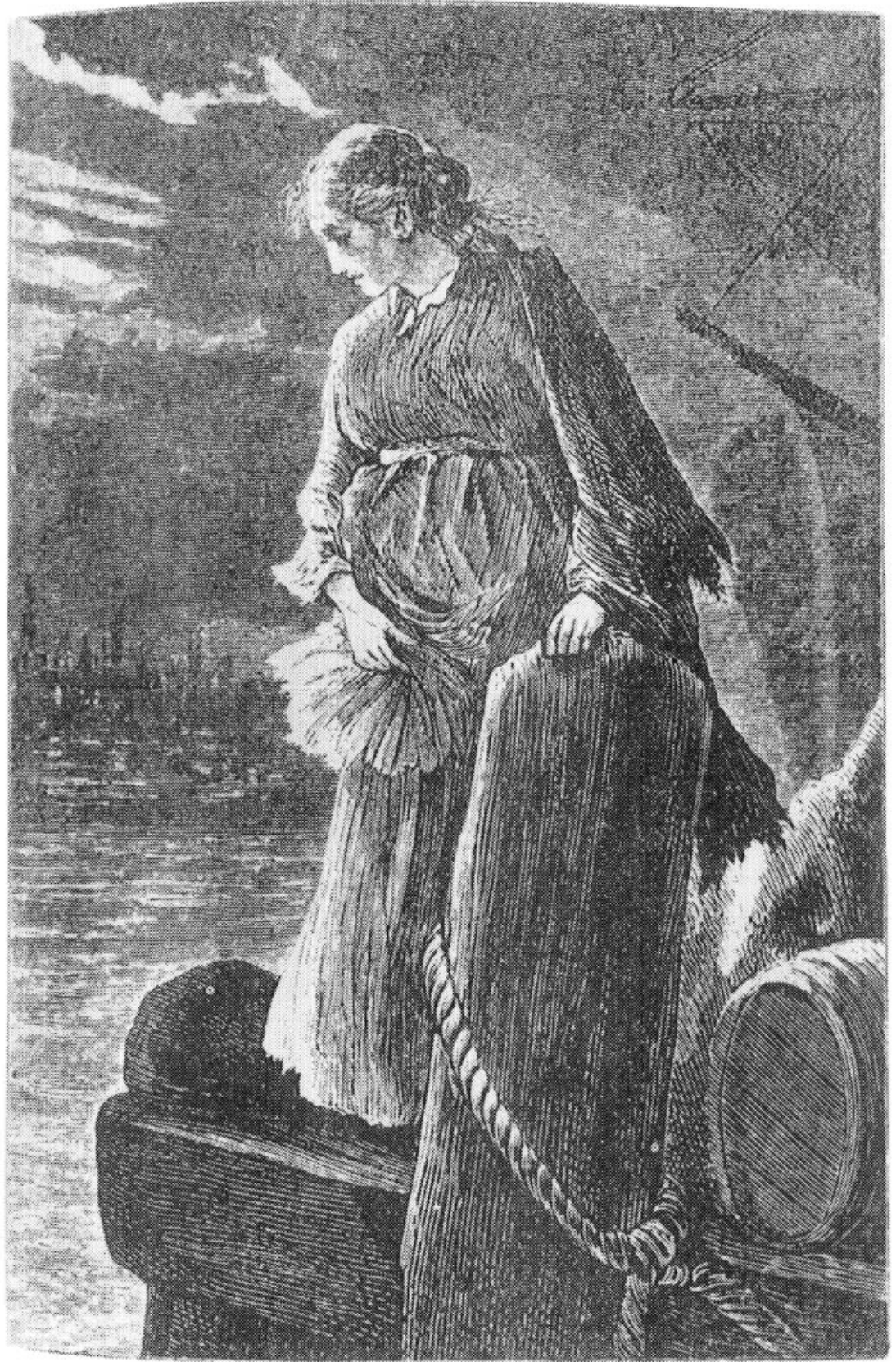

"The street-girl's end." (Charles Loring Brace, The Dangerous Classes of New York, and Twenty Years' Work Among Them. New York: Wynkoop \& Hallenbeck, 1872, reprinted NASW Classics Series, n.d., illustration opposite p. 122.) 
You are ... soon to be the leading, acting members of society; to occupy all the places of influence and trust, and to have at your disposal all the great and precious interests of the church and state. Consider now, how much depends on the character you are forming ... the welfare of this whole community ... [depends] on your possessing a character of true virtue and excellence. ${ }^{13}$

Since the character of the young and the character of the Republic were inextricably bound, leaders assumed responsibility for each. If the viability of the Republic depended upon virtue, character formation was possibly the central political concern.

It was not uncommon, at mid-century, to talk of the Republic as a growing youth. ${ }^{14}$ Thislanguagewastheheritage of the foundinggeneration:

"Republicanism was the concomitant of youth... Monarchy and hereditary aristocracy were deviations from nature, the products of oversophistication, of age and decay." ${ }^{15}$

In T.S. Arthur's analogy of individual and society, should the moral fiber of one decay or atrophy, so shall the other.

Even more deliberate were some parallels drawn between the health and liberty of the Roman republic and the morals of youth:

When Cataline [sic] attempted to overthrow the liberties of Rome, he began by corrupting the young men of the city, and forming them for deeds of daring and crime. In this, he acted with keen discernment of what constitutes the strength and safety of a community-the virtue and intelligence of its youth-especially of its young men. This class of persons, has, with much propriety, been denominated the flower of a country-the rising hope of the church and society. Whilst they are preserved uncorrupted ...the foundations of social order are secure, and no weapon formed against the safety of the community can prosper. ${ }^{16}$

Alger joined in the venerable tradition of Americans who had looked to lessons from dassical antiquity to discover what strengthens and what undermines modern republics. His 1852 English Oration Prize essay, "Cicero's Return from Banishment," highlighted thetension between virtue and corruption in Rome. Although Cicero had quelled conspiracy and was loved by "all good citizens," the ill-disposed among the powerful had succeeded in driving him into exile. Alger's sentimental tale features the triumphant return of Cicero to Rome, demanded by the popular will. "The city gates were thrown open," as Rome embraced its preserver. The Roman people were his "Captives, bound by no unwilling fetters but by the ties of gratitude and affection." But the oration-and Cicero's triumph in this account - end on an ominous note, in which the fragility of liberty and civic 
virtue are clear: "Thus closed the grandest civic triumph which the world has yet seen! It was one of the last efforts of public liberty to do honor to its patron and defender." ${ }^{\text {17 }}$

Liberty was fragile, indeed. Henry Ward Beecher and many of his dour contemporaries thought the battle was being lost on these shores in the nineteenth century. For those who issued moral warnings shaped by the language of republicanism,

Thejeremiad - that most American of all rhetorical modes-was merged with the language of classical republican theory to the point whereonecanalmostspeakofanapocalyptic Machiavellism; and this too heightened the tendency to see that moment at which corruption threatened America as one of unique and universal crisis. ${ }^{18}$

Middle class moralists in the nineteenth century repeatedly linked their concern for the morals of America's rising generation(s) with their fears for the disintegration and degeneration of the Republic. Their fears rang out in advice manuals, lectures to mercantile associations and mechanics' societies, and sermons.

\section{ADRIFT IN THE CITY: MORAL PERILS AND THE ADOLESCENT OF THE REPUBLIC}

Of all who shall finally make their bed in hell, they will have the lowest place, who, not satisfied with being wicked themselves, labor to diffuse the poison of their principles, and lure unguarded youth to the gates of death. To say of any one, "he is a corrupter of youth," is to give him the worst possible character.

Joel Hawes, Lectures to Young Men

Advicemanuals depicted many power-seeking culprits seeking toinfluence the young stranger entering the city. They posed the danger of moral and bodily harm. Virtually all manuals advised the reader how tojudgeknavery and how to deal with strangers. ${ }^{19}$ Alger is part of this discourse. The same liminal figures appear and threaten to undo the hero, morally or materially.

Alger's project for preserving the Republic from tyrants, demogagues, and enslavers was, likewise, a personal project. Vice is personified in the power-seeking deceiver and manipulator; virtue is personified in the youth who struggles for independence. 
The captivating image of the raw country youth standing on the urban threshold, ready to seek his fortune was certainly as old in this country as was Franklin's Autobiography. ${ }^{20}$ The nineteenth century image, connoting adventure, excitement, and mobility, was not novel, nor were fears for unsupervised youth.

What was, perhaps, unusual was the urgency of the fear and the frequency of its expression in mid-century. The former can be sensed in Horace Mann's words: "Torn from the parental stock and transplanted to a city, who can describe the dangers that encompass a young man during the period of his moral acclimation?" 21

There was a sense that myriad noises and sensations could overwhelm the malleable youth. "Everything leaves its impress on the young: the countenances they look at, the voices they hear, the places they visit, the company they keep, and the books they read." 22

It became ever more dangerous to trust. The unsuspecting boy was watched and marked by many eyes, such as "the seducer in the shape of the young man who came before him, and who has already lost the last remains of shame"; the pander to vice "who has as little remorse at the ruin of innocence as the alligator has in crushing the bones of the infant that is thrown into his jaws from the banks of the Ganges"; and "she-who was once the pride and hope of her parents-who now makes war upon virtue and exults in being a successful recruiting-officer of hell." Meanwhile, the youth entering the city was "generous and confiding. He mingles feelings without suspicion and is ready to believe all sincere who proffer him their friendship."z

Benjamin Franklin may not have needed an advice manual to help him enter Philadelphia and decode the city, but, for many antebellum authors, circumstances in the mid-nineteenth century city were quite different. Midcentury anxieties reflected an era of marked social mobility. ${ }^{24}$ Migration of youth to cities and immigration raised urgent issues of citizenship, along with the moral and political incorporation of strangers. So many were now flocking to the cities, including persons from abroad, whose principles were as yet unknown. Corruptors lay in wait tolure and destroy the young of the Republic.

The confusion and anonymity of the growing city created a rich opportunity to prey on strangers. So did the changing economy, with the early nineteenth century "proliferation of moveable wealth, especially negotiable paper." The combination "made possible for the first time a wide variety of swindles, frauds, forgeries, counterfeiting activities, and other confidence games." 25 
As old patterns of social deference crumbled, peer pressure was seen as a dangerous source of corruption of the morals of the young. ${ }^{25}$ "Nothing is of more importance to young men than the choice of their companions." ${ }^{27}$ Judging correctly is critical:
Every young man may see how much depends upon his choice of associates. If he mingle with those who are governed by right principles, his own good purposes will be strengthened, and he will strengthen others in return. But if he mingle with those who make light of virtue, and revel in selfish and sensual ind ulgences, he will find his own respect for virtue growing weaker, and he will gradually become more and more in love with the grosser enjoyments of sense, that drag a man downward, instead of lifting him upward, and throw a mist of obscurity over all his moral perceptions. ${ }^{28}$

The stranger who approaches the young man fresh from the countryside or small town is a seducer who is attractive because he knows his way around the city, appears to "know the ropes," and because he offers friendship, entertainment, and familiarity "at the precise moment when all familial and communal restraints were falling away." 20 The new entrant to the city was offered a quick social network in a world of strangers. ${ }^{30}$ This seducer was frequently termed a confidence man.

The term "confidence man" was probably first employed by the New York press during their coverage of the arrest and antics of an 1849 street swindler, William Thompson, who tricked several citizens out of their gold watches before his capture. Thompson, who had the appearance of a gentleman, approached anothergentleman in thestreet, chatted briefly, and asked "whether he had the confidence to lend his watch to a stranger." Handed his prize, the street artist walked off laughing. The press averred there were other such criminals operating in New York, and a survey of police captains in the 1860s estimated that confidence men represented onetenth of New York City's professional criminals. ${ }^{31}$

The confidence man was only one symbol of power against which the young needed protection; we will later discover other emerging dangers and sources of illegitimate power in the Republic. But the personified moral corruptor of youth galvanized the attention of a significant number of writers of Alger's era.

Karen Halttunen effectively demonstrates that the recurring focus on the youth's urban companion, the demagogue, and the gambler all represent anxieties about power. Such figures expressed fears about the consequences of major social, political, and economic transformations of the midnineteenth century. The confrontation between the virtuous boy and the 
confidenceman symbolizes the struggle for thevirtue of the Republic. In the confidence game, "the passive liberty of the American youth falls victim to the self-aggrandizing power of the confidence man." 20

The fear and its lexicon were holdovers from the eve of the American Revolution, when aggressive, creeping, encroaching power-likethe ocean, like a cancer, like jaws, like appetite-too often "destroys its benignnecessarily benign--victim." This victim was "liberty, or law, or right." 3

The confidence man, in assaulting character, assaults that which guards individual morality and collective virtue.

There is no charm in free institutions to sustain themselves and to bless a nation. Liberty, where the individual is the slave of his neighbor's opinion, or still worse, of his own passions and appetites, is a mere sound. ${ }^{34}$

The battle for the liberty of the boy was a battle for the liberty of the Republic and its free institutions.

For the most fearful, vulnerability was so serious that even the presence of the profligate could be considered "polluting to the soul"; contamination merely required contact. The imagery of contamination carried over from the cholera years; "the licentious man was said to be 'a pestilence in the community' who could infect everyone around him because 'his breath blights every innocent thing.'" 3 Refusal to associate with corruption was the best safeguard.

As a general rule, Alger's boys keep away from gambling dens, saloons, and the company of the corrupt. One must beware the powers of seduction. If "granny" or a father-pretender is corrupt, the boy or girl of good character tries to escape and find his or her true parents or relations.

However, Alger did not think evil was so readily contagious that good character could be contaminated on mere contact. He did not attempt to keep the boy away from all tempting experiences. Onemust bewary of boys who smoke, drink, swear, play billiards, or squander money, but these vices are not absolute guides to character, since reform is possible. ${ }^{\text {\% }}$ In Alger's version, the ramifications of contact with vice could be serious: the nearpenniless hero might be bilked for a free meal or lose his remaining money. But money and virtue were not the same. In the typical advice manual, contact leads more frequently to a slow seduction into drinking, gambling, theater, and sex..$^{3 /}$

For these authors, it was clearly important to build lines of defense against potentially corrupting influences. This included learning how to "read" character-to discern thedifference between appearanceand realityand how to develop and maintain a firm character oneself. 


\section{LESSONS IN SURVIVAL: READING CHARACTER AND DECODING THE CITY}

[Beware] the goodnatured civilities of persons you have never seen before. Gratuitous offers of assistance or advice, or good fellowship, are suspicious, to say the least. Do not be persuaded to go anywhere with these casual acquaintances.

Wood's Illustrated Hand-Book to New York ${ }^{38}$

Alger invariably putsforward somecharacter whoseappearanceis deceiving, whether urban confidence man or country squire. The device reveals how critically important is the separation of appearance, artifice, reputation, and pretence from nature (being). This concern with hypocrisy was widely shared. "Archetypal hypocrites threatened ultimately, by undermining social confidence among men and women, to reduce the American republic to social chaos." The art of such figures lay in manipulating "facial expression, manner, and personal appearance in a calculated effort to lure the guileless into granting them confidence." ${ }^{39}$

Especially when the Alger hero leaves familiar surroundings of country or small town life, heis at risk among rascals. The world becomes much less predictable and friendly. The boy is "green" and too trusting upon contact with the city, falling victim-sometimes more than once. One must be shrewd and tough to separate friend from foe, appearance from reality. The hero survives by learning how to decode the city and learning the lessons of character.

Writers of the romanticperiod valued transparency of character. Nature, not artifice, was the clue to good character. One heard that "His face was the index of his mind" or a boy's eye constituted "the perfect mirror of his mind" ${ }^{10}$ In a simple world, good character can be read off the face.

However, the world has its deceivers-perhaps in increasing number. Americans nolonger lived in a world in which they could count on honesty and plain-dealing. Too many were obsessed with gain. A businessmen complements young Ben Barclay in Store Boyby telling him: "Your honesty, my boy, is of the old-fashioned kind. It is not the kind now in vogue."4I Because it is difficult to judge those who stand on pretense or contrivances, the unsuspecting boy would do well to keep up his guard. Signs of friendship were not always what they appeared, and not all cues were readily readable. The boyneeded tolearn how to protect himself. Alger had learned enough lessons from city life to realize that naturalness could be a liability. The boy himself must be less forthcoming with strangers than a simple-natured boy would, without ever actually lying. Somehow, the 
Alger hero must participate in codes in which worthy people can read his character off his face and behavior-he must be straightforward, honest, open-hearted and sincere-while learning how to keep manipulators from reading and playing upon him. ${ }^{42}$

There is no genuine privacy for one who is unable to hide his or her feelings. As Alger repeatedly reminds readers through the vehicle of boxing, emotions can get in the way of achieving one's objective; being angry is no way to best an opponent in a fight. ${ }^{43}$ Broadcasting feelings and having moods written all over one's face are kinds of involuntary publicity that may prevent one from being in control and realizing one's legitimate purposes. When central characters assume false identities or false missions or conceal their feelings in order to advance the cause of justice, readers learn that performance (of deceivers) may necessitate performance. ${ }^{44}$

If the reader pays close attention, appearances as described by Alger are a giveaway to character in all but a very few cases. The author was interested in both phrenology and physiology, and hisheroes areladen with "positive" physical and behavioral attributes. ${ }^{45}$ They are generally described as frank, manly, sturdy, stout, resolute; attractive boys usually are given dark hair. Such boys have an open face and an air of independence and self-reliance. Alger finds physical clues to the nondepraved natures of some characters, despite their hard lives, crude manner, and bad habits. Villains look mean or ugly and tend to have behaviors and dispositions to match. They are often given red hair and sallow or pock-marked complexions.

A ppearance differentiates the evil nature from the character molded by circumstances. Looking at the description of two would-be robbers, we can see that unattractive descriptions suit those whose nature leads them to crime:

One was a short, stout man, with a heavy face and lowering expression; the other was taller and slighter, with a face less repulsive. The former, in rushing into crime, appeared to be following the instincts of a brutal nature. The other looked as if he might have been capable of better things, had circumstances been different. ${ }^{46}$

Alger teaches an important lesson in notable examples where character judgments are impossible to make on the basis of appearance. In Adrift in the City, a well-dressed man "accosted" Oliver Conrad and invited him to lunch at Delmonico's merely for the company. Oliver felt quite lucky indeed, because he was penniless. However, the gentleman lured Oliver home with him after lunch and tried to chop him up in the name of science. In this rare case, there was nothing about the character of the gentleman to tip off the reader. Oliver Conrad could not have foreseen the danger 
awaiting him after Delmonico's unless he were generally suspicious of unsolicited-or unearned-kindness. ${ }^{4}$

This story highlights the author's beware-strangers-bearing-gifts or Trojan Horse message: do not trust people volunteering something for nothing or great deals and tips, even if they look as distinguished as the old physician in the moral story. Occasionally, someone approaching the hero with an offer of a job or seeking a travelling companion to the West is on the up-and-up, but one must be perspicacious. It is understandable that Oliver accepted a meal when destitute, but it is always problematic and often dangerous to accept favors from complete strangers.

The cases in which figures appear good or evil by physiognomy would seem to generate conflict about how much control the individual has over character formation. Popular temperance tract and advice author T. S. Arthur thought that young men came in two classes: one was comprised of those who "feel the force of good principles, and are in some willingness to act from them," and the other was "composed of such as are led mainly by their impulses, feelings, passions, and selfish interests." ${ }^{48}$ For Alger, a small number were evil by nature; others simply failed in their duties and had fallen into temptation. Any great concession would have threatened the vitality of the Republic. But what class was it that could not "feel the force of good principles"? Does the capacity for goodness reside with some more than others? The question of biological parentage looms importantly in these novels; the author seems determined to demonstrate that the central character (including the orphan) springs from decent stock. If capacity for goodness (or evil) can beby inheritance, there is a darkimplication. Capacity is only potential; goodnesscan be derailed. Alger's guideto character would then be the Yankee self-preservation manual.

\section{CHARACTER: THE ANTIDOTE}

The primary meaning of the word character is a mark made by cutting or engraving on any substance, as wood, stone, or metal. Hence, as applied to man, it signifies the marks or impressions made upon the mind.

Rufus W. Clark, Lectures on the Formation of Character, Temptations and Mission of Young Men ${ }^{49}$

Filippo [Phil, the Fiddler], a rare Italian-American hero, exhibits promising character traits. His good humor and lively disposition, his resilience and optimism contrast with the despair of other boys forced to work for 
padrones or placed in similarly hard circumstances. His face was often lighted up by a smile, "for in spite of the hardships of his lot, and these were neither few nor light, Filippo was naturally merry and light-hearted." 50 The hero is bold, plucky, courageous, and hopeful. Such traits are expected of an Alger hero. ${ }^{51}$ Virtue is active, just as in the republican model. While Phil is too young to attain manhood, he is on the right track, and adoption preserves and enlarges his capacity for liberty.

Characterwas thekey tofreedom. Well-ordered character, self-discipline, and honesty were hedges against power-seeking culprits and thecorruption of the Republic. Character formation was the nineteenth century version of a self-defense course.

The boy of good character was, in the parlance of the age, manly. ${ }^{52}$ When the young "walk in the midst of allurements for the appetite," those who yield are not men but beasts. "He who cannot resist temptation is not a man." 53

One who would form a firm, self-reliant character must cultivate firm principles early in life:

... you are to be, in this life, and in that which is to come, just what your principles make you. These are the foundation and frame work of character; these, the main-spring of purpose and action $\ldots{ }^{54}$

Character was a sacred obligation: "on the character you are now forming hangs your own eternal destiny." Each must take charge of his or her own moral destiny. "By exercising self-possession, self-government, and, above all, self-reliance, he [the self-mademan] placed himself beyond evil influences and became a law unto himself." 5

Youths with fixed principles could not be led astray by companions. A frequent counsel was that "He who acts from a settled regard to duty is sure to sustain, in the eyes of his fellow men, a character of substantial excellence and worth ... he will be respected." 56 Formation of firm principles and manly character were Alger's recipe for gaining respect and having self-respect as well. Advice manual authors articulated a new version of the (self)work ethic: "you may be whatever you resolve to be. Resolution is omnipotent"; "real men" were self-made.

Boys who must count only upon themselves develop their manly selfreliance. ${ }^{\nabla}$ The presentation of the hero as orphan or apparent orphan, a common nineteenth century romantic plot device, figures in this context. With uncertain parentage and lacking place, station, or fixed identity, the Alger "orphan" creates his or her own identity and selfhood. Ragged Dick becomes, through his efforts, Richard Hunter, Esq. In the case of many of 
Alger's orphans, successful creation of selfhood is followed by revelation of true heritage and access to material comfort. The hero regains a name and birthright only as a result of producing and owning his identity, proving his character and making his own way. ${ }^{58}$

In Alger's moral universe, all real men were self-made, for one was not born virtuous. Virtueand truemanhood required work. Manliness connoted action, duty, and usefulness in the pursuit of some honorable calling. ${ }^{59}$ These were not passive or contemplative virtues. Becoming self-madeowning one's own character-entails agency, struggle. This struggle defined the hero's triumph. It is in this sense the author can actually be described as the celebrator of self-made men.

By the middle decades of the nineteenth century, Americans dreamed of self-made men. They surely thought of something other than what the advice manual authors meant. "Surely no youngman... can prefer the brute power of money before the moral power of character," speaks the plaintive voice. ${ }^{60}$ The complaint persisted: "this inordinate desire for money is the cause of countless failures. . . True manhood and true womanhood are involved in true success." 61 By mid-century, the danger of fascination with wealth would have to be confronted-it could no longer be escaped. Chapter 8 examines Alger's solution to the problem.

\section{WHAT KIND OF SCHOOLING DID MANLINESS REQUIRE?}

Alger's heroes clearly exhibit the moral and ethical conscience of the midnineteenth century Unitarians. Harvard Unitarians believed that humans were born with a moral faculty - with the potential tomake moral judgments; in this sense they were equal. In contrast to the Calvinist doctrine of predestination, Alger's Unitarian heritage offered the universality of grace. And if some few lacked the capacity for virtue, Alger's moral story is nonetheless infused with a sense of possibility.

The obligation of firm character followed from the assurance that "there are such things as truth and falsehood; as right and wrong. These are, in their nature, immutable and eternal." Immutablemoral values are discoverable.

However, moral judgments were not mere instincts. The faculty must be made conscious even possibly trained. Not all used this faculty. ${ }^{63}$ What schooling, then, did virtue require? From whence came the Alger hero's firm sense of right and wrong?

Clearly, not from a Harvard education. Alger heros were not terribly reflective and certainly not philosophical. They may have had only 
rudimentary formal schooling, and most werenot under influence of clergy. These adolescents had good instincts and discovered how to trust them. They augmented their common sense through valuable lessons learned in street school and by association with good guides. The education that tends to self-improvement was not monopolized by elites or their institutions: Neither Harvard nor the church mediated access. Alger even provided alternatives to the institution of the common school, which, in the middle decades of the century, was recommended to promote good behavior and moral development. Manylooked to the common school for the Republic's virtue and well-being; institutionalized learning and literacy could combat poverty, vice, and crime..$^{64}$ But Alger boys and girls were sometimes unschooled, or torn from school in the formative years. If they would not be lost, the institutional pillars of presumed virtue must be replaceable. Benefactors and surrogate parents replaced family and church; home learning replaced formal education. Even the poorest Alger hero was likely to acquire a book to improve himself, learning how to read or teaching himself some other part of the common school curriculum. The most untutored could acquire the moral grammar.

Alger may have modeled his fictional boys on his revered woodsman, Natty Bumppo, unschooled and living apart from civilization. He judged character very well, disregarding social distinctions that did not depend on personal merit.

A disbeliever in the ability of man to distinguish between good and evil without the aid of instruction would have been staggered by the character of this extraordinary inhabitant of the frontier... no casuist could have made clear decisions in matters relating to right and wrong. ${ }^{65}$

Catherine Zuckert terms Natty the ideal democratic citizen. He can recognize and respect differences of ability, and he has independence and strong moral sense. "Because he listens so immediately and directly to his own natural impulses and sentiments, Natty is not deceived by appearances or impressed by conventional distinctions." 6

Unschooled benevolent affectionscould goalong way towardmaintaining the Republic. Alger had faith in the boy of the adolescent Republic and staked some faith in the democratic impulse.

"It is the heart and not the brain / That to the Highest doth attain," Alger quoted from Longfellow in an ode he composed upon the latter's death in 1882. ${ }^{67}$ It is as if, with the ethical sentimentalists of Adam Smith's era, Alger found the moral sense located in the emotional, not the rational part of the soul. Among Thomas Reid's "animal" (i.e., not rational) powers were the affections: 
The benevolent affections were natural and unreflective, seeking the good of others without conscious selfishness. Since they reflected a mere "instinctive sympathy" they did not partake of virtue until blessed by the rational moral sense. Yet the benevolent affections were beneficial, even essential, to the individual, since they provided the basis for society, without which man could not exist.

Benevolent affections included "Gratitude, pity, friendship, and parental and filial love." Malevolent affections, prevalent among Alger foils, included envy, contempt, and resentment. ${ }^{68}$

However, the Harvard moralists identified the moral sense with the rational (our conscience "interprets to us God's love of virtue and hatred of $\sin ^{\prime \prime}$. According to favored philosophers Thomas Reid and Dugald Stewart, there were two rational powers: prudence and conscience. The former was self-regarding, and the latter regarded duty and was equated with the moral sense. ${ }^{6}$ Alger's boys acquired both of these "rational powers."

Alger had been influenced by ethical intuitionists and Cambridge Platonists who saw "'goodness' or 'rightness' as simple, indefinable ideas, perceived intuitively by human reason"; right-no less than truth-was self-evident if one would only look. "Good sense is good judgment," Reid held. Common sense and the moral sense were the tools to discover that one should promote the general good..$^{\text {D }}$

For Alger's Unitarian mentors, sentiments were an aid to conscience. According to William Ellery Channing, "Sentiment is not mere feeling ... it is feeling penetrated with thought." Reason and desire were joined when "the good life meant achieving a delight in virtue."71 But since virtue required more than benevolent affections, the Alger hero who chose to perceive duty joined an elite class.

Selfishness was associated with acting upon desires contrary to the interests of the community. Self-love was different. Gambling, drinking, smoking, and self-indulgent spending were merely selfish. In the view of T.S. Arthur, "Our object is, to make him [the boy] feel that he does not stand alone in the world, and therefore should never permit himself to act from purely selfish principles." 72 License is selfish. "Men were not created for mendicity societies, and almshouses, and the gallows; but for competence, and freedom, and virtue."73 Responsibilities and duties the individual maintained toward society and toward other individuals loomed far larger in the discussion of these nineteenth century moralists than did rights.

Self-love was prudential self-regard and was generally not at odds with conscience or duty; the temperance man displayed respect for himself and 
also followed the dictates of conscience. Seeking comfort or gratification of desires were not evils per se, but "the appetites required regulation by higher powers." 74 Prudence was consistent with the moderate gratification of desires and appetites; it wasinconsistent with violence and self-indulgence.

Temperance, modesty, honesty, restraint of anger, self-improvement, industry, frugality-virtues of Alger's boys and featured in the advice barrage from preachers-all partook of self-love and were components of duty. ${ }^{\text {T }}$

The virtuous person had, then, a balanced character; "True greatness... [lay in] self-mastery." Moderation and self-mastery produced freedom. "Only when a man was following the guidance of prudence and the moral sense was he free," according to Reid. The corollary was that "the man who was not the master of himself was the servant of sin."76

Alger internalized this Christianized Plato. If sophrosyne was the particular virtue of the bronze class in The Republic, it was the virtue of the ideal democratic citizen formulated in Harvard Yard.

\section{IMPROVEMENT, OPTIMISM, REFORM}

Beware of companions whose moral character is below your own, unless you associate with them only to reform them. Avoid those who depreciate true worth, and speak lightly of the best class of citizens, and sneer at reforms...

William Makepeace Thayer, Success and Its Achievers

Didactic though Alger's fiction may be, he translated much of the moral content of advice manual literature into a more lively and optimistic picture. If characters faced all the same dangers, the author nonetheless managed to play the exorcist. Villainous personae of the drama do not ultimately drag down the adolescent of the Republic. Setting the young down virtually alone in the city, Alger found good moral influences for them. Heroes could become men, even in the city of strangers and loose morals.

Those armed with the proper character would help others overcome moral danger. Ragged Dick; Mark, the Match Boy; Tattered Tom; Dodger in Adrift in New York, and Sam Barker from Young Outlaw and Sam's Chance all stand in testiment to the power of reform. Far from model young people, they only progress gradually toward good habits and respectability. Even the hero who steals on the street, from an employer, or from a friend can be rehabilitated through the good influence of another boy, a benefactor, or a lovely little girl." A little moral encouragement and respect goes a long way 
for the ex-clergyman. Therefore, it follows (in the words of another advice author):

All good members of society ought to make it an object, to give special patronage and encouragement to young men of worth and character... if young men could once be convinced that the patronage and favor of the respectable part of the community, and consequently their success inlife, depend on their possessing a fair, unimpeachable character, it would have the happiest influence on their morals and habits. ${ }^{78}$

Since individual example can cure individual vice, the young people addressed should, themselves, "perform the angelic office of guardians and advisers to those who are younger than yourselves, and wholook to you for example." 79 Alger's heroes do exactly this. Armed with firm character, they help safeguard the morals of the new generation, promote the interests of the community, and demonstrate that we can become more-rather than less-moral.

When first met, Alger's boy of common sense (wherever this sense is located) has good instinct but not yet virtue. Virtue requires some reflection and choice between good and evil. ${ }^{80}$ Young protagonists acquire the capacity touse their rational moral sense only upon confronting and making moral choices. This confrontation requires exposure.

Contact and conflict with evil became the necessary condition of moral effort, thought clergyman Thomas Hughes:

In that strife, then, the first requisite is courage or manfulness, gained through conflict with evil, -for without such conflict there can be no perfection of character, the end for which Christ says we were sent into this world. ${ }^{\text {sI }}$

Alger apparently concurred. Innocence may sustain community, but innocence is not virtue. With the transition to manhood, the Alger hero acquires consciousness and conscience.

Alger sometimes remarked that going to the city was a kind of gamble that the young should not make if the odds of a decent life at home were good. Virtue was more easily protected, if less constantly tested, in the countryside. If the only way the boy could become "manly" was by having to choose between good and evil, what better choice than the city? Thus, it seems, the dialogue with the city must be joined after all.

The author dealt with this tension by providing a doubly happy ending to the rites of passage. One observer found that Alger

... essays a half-solution by representing his heroes as bringing to Sodom the leaven of their home-town virtues. They improve 
New York's moral tone and in exchange New York makes them rich. $^{82}$

"The city must be recovered, recaptured as the city upon a hill." youth confronts the perils of the city and both benefit. The hero becomes one of those to whom society can look for its regeneration. ${ }^{84}$ By encouraging reform, heroes are actively preserving the Republic.

Character rehabilitation is social reform; it is the endproduct of political reform. The rehabilitation of Ragged Dick and his confrères suggests something quite different from degeneration. The Republic, through contact and association with vice, has lost its innocence. Only with trial and confrontation, however, can it hope to partake of virtue.

\section{REPRISE}

Contemporary jeremiads lamented the corruption that threatened a unique Republic with disintegration and degeneration, but their authors were generally ill-equipped to reach those who dreamed of the excitement of urban life, of opportunities, of the wonder of growth and change. Those lecturingyouth-clergymen (John Todd, Joel Hawes, Henry Ward Beecher), educational reformers (William A. Alcott, Horace Mann), and popular sentimental writers (Timothy Shay Arthur) urged the formation of moral character, and, more often than not, feared the battle would belost. ${ }^{85}$ Alger's fiction also recalled the young to their original principles. But the tone of alarm in the face of danger was not there: he expected this battle to be won.

In Alger's allegory, authority of conscience and continuity of character were essential. Some subset of adolescents must win this struggle if the freedom and integrity of the community were to be preserved. However, even those who fell short of true morality but who were guided by good instincts contributed importantly to the task. The "gratitude and affection" with which the Roman people bound themselves to Cicero-benevolent affections, not virtue-would always remain the most powerful bonds in the community. For theoptimist, those who were not vicious but who either avoided confrontation with evil or whofell short in the struggle to attain true manhood could, nonetheless, recognizeand appreciatevirtue. Both dassesheroes and their welcomers-contribute to the happy prognosis for the adolescent Republic.

Alger never wavered in his moral certitude. The principles by which one should live and according to which members of society should treat one another were eternal. At this level, the universe was known and knowable. 
On theeve of the twentieth century, most Americans probablystill presumed themorality of the universeand felt certain of moral and political judgments. Religions could adhere to such a worldview in the twentieth century, along with westerns and other genres in popular culture. However, by the end of World War I, men and women in intellectual and literary circles lost this moral certainty. ${ }^{87}$ This turning point may demarcate a real end to the illusion of unity between elite and mass culture. 
82. Alger, "Athens," pp. 38-39.

83. Alger, "Athens," pp. 38-40.

84. Alger, "Athens," p. 41.

85. Alger, "Athens," pp. 44-45.

86. Alger, "Athens," pp. 42-43, quoting an unnamed modern writer.

87. Alger, "Athens," p. 44 tries to use Plato's Republic to defend the Sophists on the grounds that a vicious society will have vicious teachers and that even the best teachers will not produce a good effect in a vicious society.

88. W. R. Alger, Life of Edwin Forrest, Vol. 1, pp. 17-18; henceforth, Forrest.

89. Alger, "Athens," pp. 41-42. For Alger's dependence upon his earnings as a writer, see Scharnhorst and Bales, Lost Life, especially Chapter 1.

90. W. R. Alger, Forrest, Vol. 1, p. 18.

91. W. R. Alger, Forrest, Vol. 1, pp. 18-19.

92. Alger, "Athens," p. 40.

93. Alger, "Athens," pp. 38, 25-27, 29.

94. Alger, "Athens," pp. 31-33.

95. Alger, "Athens," p. 37.

96. Alger, "Athens," p. 46.

\section{CHAPTER 3}

1. Hawes, Lectures to Young Men, p. 113.

2. Todd (1850), p. 76. Quoted in Halttunen, Confidence Men and Painted Women, p. 47.

3. Hawes, Lectures to Young Men, pp. 97-98: "More is done during this period [from fourteen to twenty-one years of age] to mould and settle the character of the future man, than in all the other years of life."

4. Halttunen, Confidence Men and Painted Women, p. 1. Halttunen's work provides a superb discussion of antebellum advice manuals.

5. See Halttunen, Confidence Men and Painted Women, pp. 10, 15.

6. The Alger hero will be referred to as "he" since young boys were the chief heroes. However, Tattered Tom, Helen Ford, A Disagreeable Woman, Mabel Parker, and $A$ Fancy of Hers all feature heroines.

7.Timothy Shay Arthur, Advice to Young Men on Their Duties and Conduct in Life, p. 56. 
8. Joseph Kett's Rites of Passage: Adolescence in America, 1790 to the Present (New York: Basic Books, 1977) argues that early nineteenth-century American culture has no clearly defined rites of passage to manhood; it is unclear at what moment a boy becomes a man. See also Halttunen, Confidence Men and Painted Women, p. 27.

9. Charles Loring Brace, The Dangerous Classes of New York (New York: Wynkoop \& Hallenbeck, 1872; reprinted NASW Classic Series, n.d.), pp. 300-1. Brace wrote of their fourteen to eighteen year old constituency, "... a more difficult class than these to manage, no philanthropic mortal ever came in contact with. The most had a constitutional objection to work; they had learned to do nothing well, and therefore got but little wages anywhere..." (pp. 307; 303-15).

10. Alger, Tattered Tom (Philadelphia: Henry T. Coates \& Co., n.d., copyright Horatio Alger, Jr., 1899), p. 282.

11. Theodore Dreiser, Sister Carrie (New York: Modern Library, 1917), p. 2.

12. William A. Alcott, The Young Man's Guide, 16th ed. (Boston: T. R. Marvin, 1844), p. 139.

13. Joel Hawes, Lectures to Young Men, p. 114.

14. Halttunen, Confidence Men and Painted Women, p. 10.

15. Gordon S. Wood, The Creation of the American Republic, 1776-1787 (New York: W. W. Norton, 1969), p. 100.

16. Joel Hawes, Lectures to Young Men, p. 1.

17. Alger, "Cicero's Return From Banishment," HUA.

18. J. G. A. Pocock, The Machiavellian Moment (Princeton, N.J.: Princeton University Press, 1975), p. 513.

19. See, for example, Alcott, The Young Man's Guide, pp. 133-40.

20. Halttunen, Confidence Men and Painted Women, pp. 3, 27.

21. Horace Mann, A Few Thoughts For A Young Man, p. 7.

22. Halttunen, Confidence Men and Painted Women, pp. 3-4, quoting David Magie, The Spring-time of Life.

23. Halttunen, pp. 2-4, quoting respectively John Todd's The Young Man and Jared Bell Waterbury, Considerations for Young Men. She points out that Franklin had his share of confidence men and women to deal with; the Autobiography is, itself, an advice manual.

24. Halttunen, Confidence Men and Painted Women, p. 3.

25. Halttunen, Confidence Men and Painted Women, p. 7, citing Lane, Policing the City.

26. Halttunen, Confidence Men and Painted Women, p. 13. 
27. Hawes, Lectures to Young Men, p. 102.

28. T. S. Arthur, Advice to Young Men, quote p. 55; see Chapter 5 generally. See also Alcott, The Young Man's Guide, pp. 133-40.

29. Halttunen, Confidence Men and Painted Women, p. 11.

30. See Alcott, The Young Man's Guide, p. 139. Halttunen, Confidence Men and Painted Women, pp. 2, 12-13, makes this point effectively.

31. Halttunen, Confidence Men and Painted Women, pp. 3, 6, 7.

32. Halttunen, Confidence Men and Painted Women, pp. 9-11. I argue against the notion of passive liberty below.

33. Bernard Bailyn, Intellectual Origins of the American Revolution (Cambridge, Mass.: Harvard University Press, 1957), pp. 56-57. See also Halttunen, Confidence Men and Painted Women, p. 38.

34. Artemus Bowers Muzzey, The Young Man's Friend, quoted in Halttunen, Confidence Men and Painted Women, p. 9.

35. Halttunen, Confidence Men and Painted Women, pp. 4-5, quoting Rufus Clark, Beecher, Seven Lectures, and citing Charles E. Rosenberg, The Cholera Years.

36. Alger played billiards. He wrote Edwin R. A. Seligman from California on 13 March 1877: "As to billiards, I have played about eight games with a Philadelphia gentleman, at the Palace Hotel, and that is all. Still I can probably discount you when we play again." $\mathrm{CU}$.

37. Halttunen, Confidence Men and Painted Women, p. 2.

38. Wood's Illustrated Hand-Book to New York and Environs (New York: G.W. Carelton, 1873), p. 27.

39. Halttunen, Confidence Men and Painted Women, preface, $x v$.

40. T. S. Arthur, Advice to Young Men, p. 18.

41. Alger, Store Boy (Philadelphia: John C. Winston, n.d.; copyright Porter \& Coates, 1887), p. 257.

42. On reading character off the face and on the importance of straightforwardness, see, for example, Hawes, Lectures to Young Men, p. 77.

43. Heroes frequently study boxing, and Alger himself was versed in this gentlemanly skill. "Two boys knocked at my door the other day and asked if I would teach them to fight-I declined-I don't give free lessons in fighting any longer." Alger to Edwin R. A. Seligman, March 13, 1877 from California; CU.

44. See Chapters 7 and 9 in this book on the avoidance of performance in other circumstances. See also Philip Fisher, "Appearing and Disappearing in Public: Social Space in Late-Nineteenth-Century Literature and Culture," in Sacvan Bercovitch, ed., Reconstructing American Literary History (Cambridge, 
Mass.: Harvard University Press, 1986), p. 185.

45. See Scharnhorst, Horatio Alger, Jr., p. 89, on Alger's interest in phrenology and physiology.

46. Alger, Rough and Ready (Philadelphia: Porter and Coates, 1869), p. 244.

47. Alger, Adrift in the City (Philadelphia: John C. Winston, 1895), pp. 151-64. After his ordeal, he does accept an envelope, given "in reparation for the danger" to which he had been exposed, by the son of the mad physician. The destitute hero later opens it to find $\$ 100-$ quite a cushion against any future need to accept a stranger's invitation to lunch.

48. T. S. Arthur, Advice to Young Men, p. 3.

49. Clark, p. 28, quoted in Halttunen, Confidence Men and Painted Women, p. 4.

50. Alger, Phil, the Fiddler (Chicago: M. A. Donohue, n.d.), p. 1, although heroes are not usually termed "light-hearted."

51. See R. Richard Wohl, "The 'Rags to Riches Story': An Episode of Secular Idealism," pp. 501-6 in Reinhard Bendix and Seymour Martin Lipset, eds., Class, Status, and Power (New York: The Free Press, 2d ed., 1966), p. 503. See also Chapter 8 below.

52. Hawes, Lectures to Young Men, p. 69: a life spent in diversion, pleasure, and amusement is "utterly inconsistent with all manliness of thought and action."

53. Horace Mann, A Few Thoughts For A Young Man, pp. 13-14, 70.

54. Hawes, Lectures to Young Men, p. 65; subsequent quote p. 116.

55. Halttunen, Confidence Men and Painted Women, p. 25.

56. Hawes, Lectures to Young Men, pp. 74, 83; Lecture III in general.

57. Here, the message seems compatible with Carnegie's advice to wealthy men not to leave their sons too well provided, because they will lack ind ustry in "The Gospel of Wealth". See Rychard Fink's introduction to Ragged Dickand Mark, the Match Boy (New York: Collier, 1962), pp .25-27 for a discussion of similarities and differences in the positions of Alger and Carnegie. The case that Alger's position is antithetical to Social Darwinism is made in Scharnhorst, Horatio Alger, Jr., and Zuckerman, "Nursery Tales."

58. See Walter Benn Michaels, The Gold Standard and the Logic of Naturalism (Berkeley, Calif.: University of California Press, 1988), pp. 9-10. Henceforth, Gold Standard.

59. Hawes, Lectures to Young Men, p. 69.

60. Horace Mann, A Few Thoughts for a Young Man, p. 65.

61. Thayer, Success and Its Achievers, pp. 272-73 (1896 ed.).

62. Joel Hawes, Lectures to Young Men, p. 80. See also Lecture IV. 
63. Howe, Unitarian Conscience, p. 54, discussing the views of Channing and Walker, President of Harvard.

64. See Lee Soltow and Edward Stevens, The Rise of Literacy and the Common School in the United States (Chicago: University of Chicago Press, 1981), pp. 85-86, 190 and 197. Edward Everett, "The Education of the Poor," Remarks at the examination and exhibition of the Everett School, 20th July, 1863, in Orations and Speeches on Various Occasions. 4 Vols. (Boston: Little, Brown, 1868).

65. James Fenimore Cooper, The Pathfinder (New York: Modern Library, 1952), p. 121.

66. Catherine Zuckert, Natural Right and the American Imagination (Savage, Md.: Rowman and Littlefield), p. 48.

67. Alger, untitled poem dated Dec. 18, 1882; UVa.

68. Howe, Unitarian Conscience, p. 58, discussing the Harvard lectures of Levi Frisbie. According to Howe, Frisbie followed Reid's system and his distinction between malevolent and benevolent affections. In the first quote, Reid is represented by Frisbie.

69. Howe, Unitarian Conscience, p. 53, quoting William Ellery Channing; p. 58.

70. Howe, Unitarian Conscience, p. 46; Thomas Reid quoted p. 48; see also p. 56. On the general good, see Henry Ware, Sr.'s lectures discussed p. 50.

71. Channing quoted in Howe, Unitarian Conscience, p. 62; Howe, p. 63.

72. T. S. Arthur, Advice to Young Men, p. 19.

73. Horace Mann, A Few Thoughts for a Young Man, p. 12.

74. Howe, Unitarian Conscience, p. 58 discussing the lectures of Levi Frisbie. See Howe, pp. 58-64.

75. Alcott, Young Man's Guide, pp. 62. 93, 108. T. S. Arthur, Chapter 4.

76. Howe, Unitarian Conscience, p. 61, quoting William Ellery Channing; p. 60.

77. Some older characters appear evil but mend their ways and live modest, decentlives, usually because of the influence of the boy. Occasionally a hero's soonto-be-mentor has vices such as gambling, drinking, or playing billiards; he is saved from robbery or even murder by our hero, who happens upon the scene. The wealthy (young) man generally becomes reformed and more careful of his money and his life through contact with the hero, who he may even adopt, as in Tony, the Tramp. The motif of the virtuous little girl (as in Sam's Chance) resembles Oliver Optic's more moralistic tales, where a young girl is responsible for the reform of the hero and his exposure to the Bible.

78. Hawes, Lectures to Young Men, p. 60.

79. Hawes, Lectures to Young Men, p. 61. 
80. On this theme, see Howe, Unitarian Conscience.

81. Thomas Hughes, The Manliness of Christ, pp. 5-6. The English clergyman's work was printed in Boston and New York: Houghton Mifflin Company, n.d. [lectures dated 1879].

82. Clifton Fadiman, "Party Of One," Holiday 21 (February, 1957): 118.

83. Alan Trachtenberg on Alger's Ragged Dick in The Incorporation of America (New York: Hill and Wang, 1982), p. 107.

84. T.S. Arthur, Adviceto Young Men, p. 3: "society looks to the [young men who feel the force of good principles] . . . as her regenerators."

85. Halttunen, Confidence Men and Painted Women, p. 28.

86. Henry F. May, The End of American Innocence, pp. 9-10.

87. See May, The End of American Innocence, pp. 7-9.

\section{CHAPTER 4}

1. I am indebted to Robert Darnton's "Peasants Tell Tales," in The Great Cat Massacre (New York: Basic Books, 1984), for a view of hardship in the world of eighteenth century peasants' tales.

2. Tompkins, Sensational Designs, p. xvii, xviii.

3. On the significance of formula writing, see John Cawelti, Adventure, Mystery, and Romance, and Janice Radway, Reading the Romance (Chapel Hill: University of North Carolina Press, 1984). The A-Team, Thomas Magnum, "Miami Vice," and current weekly television dramas provide modern incarnations of formula writing and ritual repetition. The functionalist reading of formula writing derives from Cawelti. Jameson, "Ideology, Narrative Analysis, and Popular Culture," 547-48 critiques Cawelti's approach.

4. Tompkins, Sensational Designs, p.xvii, for ioth quotes. The second refers to several novels prior to 1860 .

5. See Jane Tompkins' discussion of stereotyping Indians in Cooper's works; Sensational Designs, Ch. 4.

6. United States Department of Commerce, Bureau of the Census, Statistical Abstract of the United States, 1985, 105th ed., Table 123. Historical Statistics, Bicentennial Edition, Series C 89-119. (Washington, D.C.: Government Printing Office).

7. Tompkins, Sensational Designs, p. xvi.

8. Alger, Phil, the Fiddler, pp. 173-74.

9. United States Department of Commerce, Bureau of the Census, Historical 